Електронне наукове фахове видання "Ефективна економіка" включено до переліку наукових фахових видань України з питань економіки (Наказ Міністерства освіти і науки України від 29.12.2014 № 1528) www. economy.nayka.com. ua | № 8, 2019 | 29.08.2019 p.

DOI: $10.32702 / 2307-2105-2019.8 .45$

УДК 332.1

Н. О. Андрусяк, кандидат економічних наук, дочент, кафедри економіки підприємства, обліку і аудиту, Черкаський наџіональний університет імені Богдана Хмельницького

ORCID: 0000-0001-8939-7750

\title{
ІНСТИТУЦЙНІ ЕЛЕМЕНТИ КОНКУРЕНТОСПРОМОЖНОСТІ РЕГІОНІВ
}

\author{
N. Andrusyak \\ Candidate of Science (Economics), associate professor, department of enterprise economics, \\ accounting and auditing, The Bohdan Khmelnytsky National University of Cherkasy
}

\section{INSTITUTIONAL ELEMENTS OF REGIONAL COMPETITIVENESS}

У статті розглянуто та згруповано основні складові інституційного забезпечення конкурентоспроможності регіонів та запропоновано комплекс напрямів $i$ заходів, спрямованих на забезпечення еколого-економічного конкурентоспроможного розвитку економіки регіону. Автором обтрунтовано, щуо при розробці напрямів і конкретних заходів щуодо забезпечення стабільного інституційного розвитку еколого-економічної конкурентоспроможності регіонів необхідний системний підхід, щзо передбачає необхідність вивчення інституиійних особливостей регіонів Украйни, створення сприятливого економічного та правового середовища, удосконалення інфраструктури розвитку регіональних систем, послідовності вдосконалення інституційних умов та інструментів екологічної політики, чого неможливо досягти без проведення стимулювання розвитку регіонів органами державної та регіональної влади. $B$ результаті вдалося сформулювати основні стратегічні напрями реформування організацій і форм взаємодії еколого-економічних прочесів та інститутів.

The article considers and groups the main components of institutional support for the competitiveness of regions and proposes a set of directions and measures aimed at ensuring the ecological and economic competitive development of the region's economy. The need to regulate the processes of increasing regional ecological and economic competitiveness of the region is the need for institutional development of effective public administration in the environmental sector at the regional level. The institutional environment is crucial for the reproduction of the regional economic system, which implements the complex industrial, economic, social, environmental, and everyday relationships of all civil society actors. Ecological and economic aspects of structural restructuring of the regional economy should be considered in close connection with the natural product vertical, taking into account the possibilities of using the most effective ways of converting natural raw materials and obtaining on the basis of the final product, which will provide increased regional added value, as well as allow to consider the optimal redistribution of human, material and financial resources in favour of resource-saving technologically advanced industries and individual species $s$ activities. Implementation of regional policy measures in all regions requires the introduction of new coordination 
approaches, the use of a whole set of innovative management technologies that cover a wide range of solutions to social, economic and environmental problems. The author substantiates that the development of directions and concrete measures to ensure stable institutional development of ecological and economic competitiveness of regions requires a systematic approach, which requires the study of institutional features of the regions of Ukraine, creation of a favorable economic and legal environment, improvement of the infrastructure of regional systems development, following and environmental policy instruments that cannot be achieved without Art mulyuvannya regional development by state and regional authorities. As a result, it was possible to formulate the main strategic directions of reforming organizations and forms of interaction between ecological and economic processes and institutions.

Ключові слова: конкурентоспроможність; регіон; інституційні складові; екологоекономічна безпека; економічний розвиток.

Keywords: competitiveness; region; institutional components; ecological and economic security; economic development.

Постановка проблеми. Процеси глобалізації висувають комплексні вимоги до стратегічних пріоритетів розвитку еколого-економічної конкурентоспроможності регіонів як об'єктивної передумови формування та подальшого перспективного розвитку ринку екологічних послуг в форматі цивілізаційних норм і принципів. Виважені та обгрунтовані стратегічні пріоритети створюють очевидні i, на думку автора, необхідні основи до формування механізму регулювання взаємодії еколого-економічних процесів та інститутів на ринку екологічних послуг.

Тенденції економічного розвитку, що склалися на міждержавному рівні на протязі останніх десятиліть, зумовили зміну взаємовідносин всіх ринкових суб'єктів. Характерною їх рисою стали ускладнення i певна суперечливість, що пов’язано 3 самим характером глобалізації, яка руйнує адміністративні бар'єри між країнами, стимулює рух капіталів та робочої сили, загострює конкуренцію, підвищує рівень інформатизації та екологізації суспільства, та обгрунтовує актуальність створення стратегічного підгрунтя для подальшого розвитку еколого-економічної конкурентоспроможності регіонів.

Аналіз останніх досліджень і публікацій. 3 початку дослідження цього явища і до цих пір не виробилась єдина думка щодо конкурентоспроможності регіонів. Пов'язано це із розвитком парадигми регіонального розвитку. Але незважаючи на це, дослідженням даного явища займалось багато зарубіжних і вітчизняних науковців, зокрема: Антонюк Л., Брикова І., Василенко В., Глуська Н., Горбаль Н., Журба I, Калюжнова Н., Камані Р., Ковальська Л., Кузьмін О., Мельник М., Реутов В., Червова Л., Шеховцева Л. та iн.

Формулювання цілей статті. Метою даного дослідження є розкриття складових інституційного забезпечення конкурентоспроможності регіонів та їх взаємозв'язків.

Виклад основного матеріалу. Економічне зростання українських регіонів можливе лише за умови впровадження ефективних соціально-економічних та еколого-економічних відносини, що впливають на регіональну динаміку, а також на їх потенціал та сприяють посиленню конкурентоспроможності економіки шляхом використання ефективних інструментів та механізмів.

Необхідність регулювання процесів нарощування регіональної еколого-економічної конкурентоспроможності регіону полягає у необхідності інституційної розбудови ефективного державного управління в природоохоронній галузі саме на регіональному рівні. Інституціональне середовище має вирішальне значення для відтворення регіональної економічної системи, в якій реалізуються складні виробничі, економічні, соціальні, екологічні, побутові відносини всіх суб’єктів громадянського суспільства [1].

Реалізація заходів регіональної політики на території всіх регіонів вимагає запровадження нових координаційних підходів, застосування цілого комплексу інноваційних управлінських технологій, які охоплюють широкий спектр вирішення соціальних, економічних та екологічних проблем [2].

У даному контексті особливу значущість отримують питання, пов'язані із успішною реалізацією регіональної інноваційної політики, спрямованої на інституційно-правове забезпечення регіонального еколого-економічного розвитку, де невизначеним залишається правовий статус більшості інститутів, призначених стимулювати регіональний розвиток. Слід також відзначити, що регіональне правове поле суб'єктів інноваційної діяльності має бути закріплене у відповідних законодавчих актах.

Свого завершення також потребують розпочаті реформи місцевого самоврядування, зокрема у частині унормування основних засад та принципів диверсифікації регіональної економіки, самостійності регіонів у виборі стратегічних пріоритетів розвитку, що створює об'єктивні передумови залучення міжнародної технічної допомоги на потреби регіонального розвитку. 
На регіональному рівні інноваційна політика має бути націлена насамперед на адаптування до ринкових перетворень, що обумовлено різними чинниками - економічними, екологічними, інституційними, політичними тощо. Нові виклики в просторі регіонів мають бути пов'язані і з потребами власного виробництва, виходячи 3 особливостей спеціалізації окремих територій, характеру їх структурних диспропорцій і технологічного рівня, з рівнем інноваційної активності та наявністю відповідної економічної бази для виробництва інноваційного продукту [3]. Для вирішення окреслених першочергових завдань в роботі пропонується комплекс напрямів і заходів, який доцільно реалізовувати у рамках регіональної економічної політики для підвищення еколого-економічної конкурентоспроможності регіонів шляхом стимулювання інноваційної активності (табл. 1).

Таблиця 1.

Комплекс напрямів і заходів, спрямованих на забезпечення еколого-економічного конкурентоспроможного розвитку економіки регіону

\begin{tabular}{|c|}
\hline $\begin{array}{c}\text { Напрями забезпечення } \\
\text { конкуренто- } \\
\text { спроможності регіону }\end{array}$ \\
\hline
\end{tabular}

Орієнтація виробничої сфери регіону на інноваційний розвиток

Формування на базі незавантажених площ підприємств виробничих майданчиків малих інноваційних фірм; надання податкових пільг на придбання високотехнологічного устаткування; пільгове оподаткування підприємств, що беруть участь у реалізації пріоритетних державних і регіональних інноваційних проектів, зокрема екологічної спрямованості

Створення й стимулювання діяльності венчурних фондів, регіональних фондів

Залучення джерел фінансування для екологоекономічного розвитку регіону прямих інвестицій; створення приватно-державних фондів фінансування окремих стадій розвитку інноваційного бізнесу; сумісне проектне фінансування НДДКР суб'єктами регіону, які виконуються за напрямками, пріоритетними для регіону (енергозбереження, екологія, нанотехнології та ін.); стимулювання комерційних банків та інших фінансово-кредитних установ, що кредитують виконання інноваційних проектів

Підвищення результативності регіонального управління територією

Підвищення ступеня погодженості, оперативності взаємодії регіональних органів влади 3 державними органами в питаннях інноваційного екологоекономічного розвитку; розробка системи індикаторів для оцінки екологоекономічного розвитку регіону; моніторинг ефективності реалізації програмних заходів

Удосконалювання

організаційного

забезпечення розвитку

економіки регіону на

інноваційній основі

Розробка й прийняття концептуальних документів 3 питань регулювання інноваційної діяльності (стратегії й програми регіонального інноваційного розвитку, концепція науково-технічної політики регіону, та ін.); усунення адміністративних бар'єрів для старту та розвитку малого та середнього інноваційного бізнесу

Розвиток інфраструктури з 1 Підвищення ефективності урахуванням екологізації інфраструктури, спрямованої на підтримку еколого-економічного розвитку; інноваційного розвитку

забезпечення реалізації інноваційного потенціалу регіону на основі інститутів розвитку; формування технологічних майданчиків

$$
\text { Джерело: розробка автора }
$$

Таким чином, реалізація розробленого комплексу напрямів і заходів буде сприяти не тільки раціональному вибудовуванню елементів механізму забезпечення еколого-економічної конкурентоспроможності на основі реалізації інноваційного потенціалу регіонів, але й в остаточному підсумку дозволить адаптувати соціально-економічне середовище регіонів України до глобальних викликів. Перевагою такого підходу є створення рівних можливостей для регіонів з різним потенціалом розвитку, у результаті чого диференціація якісних ресурсних характеристик регіонів стає не перешкодою, а додатковим джерелом розвитку, у тому числі й інноваційного, для кожного з них і для країни в цілому [4].

На нашу думку, еколого-економічні аспекти структурної перебудови економіки регіонів необхідно розглядати в тісному взаємозв'язку 3 природно-продуктовою вертикаллю 3 урахуванням можливостей застосування максимально ефективних способів перетворення природної сировини та одержання на ії основі кінцевого продукту, що забезпечить збільшення регіональної доданої вартості, а також дозволить враховувати оптимальний перерозподіл людських, матеріальних та фінансових ресурсів на користь ресурсозберігаючих технологічно передових галузей та окремих видів діяльності.

Сучасні підходи до вирішення екологічних проблем відштовхуються від природних ресурсів, обсягів їх використання. Традиційне еколого-економічне мислення можна описати моделлю, в якій на вхід подаються природні ресурси, а як вихід беруться кінцева продукція та різного роду забруднення та деформація навколишнього середовища, утворення відходів тощо. За традиційною логікою при нестачі виробленої продукції очевидна необхідність подавати на вхід більше природних ресурсів, при цьому функціонування економіки всередині цієї моделі залишається без уваги. При такому підході боротьба із забрудненнями навколишнього природного середовища, відходами, деградацією природних ресурсів на 
виході регіональної економічної системи являє собою боротьбу з наслідками техногенного економічного розвитку [5]. Для забезпечення реального вирішення екологічних проблем, формування екологоекономічного конкурентного розвитку регіонів необхідно розглянути економіку всередині моделі, оцінити ефективність функціонування економічних структур 3 екологічних позицій та розробити інституційні напрями подальшого розвитку еколого-економічної конкурентоспроможності регіонів (рис. 1).

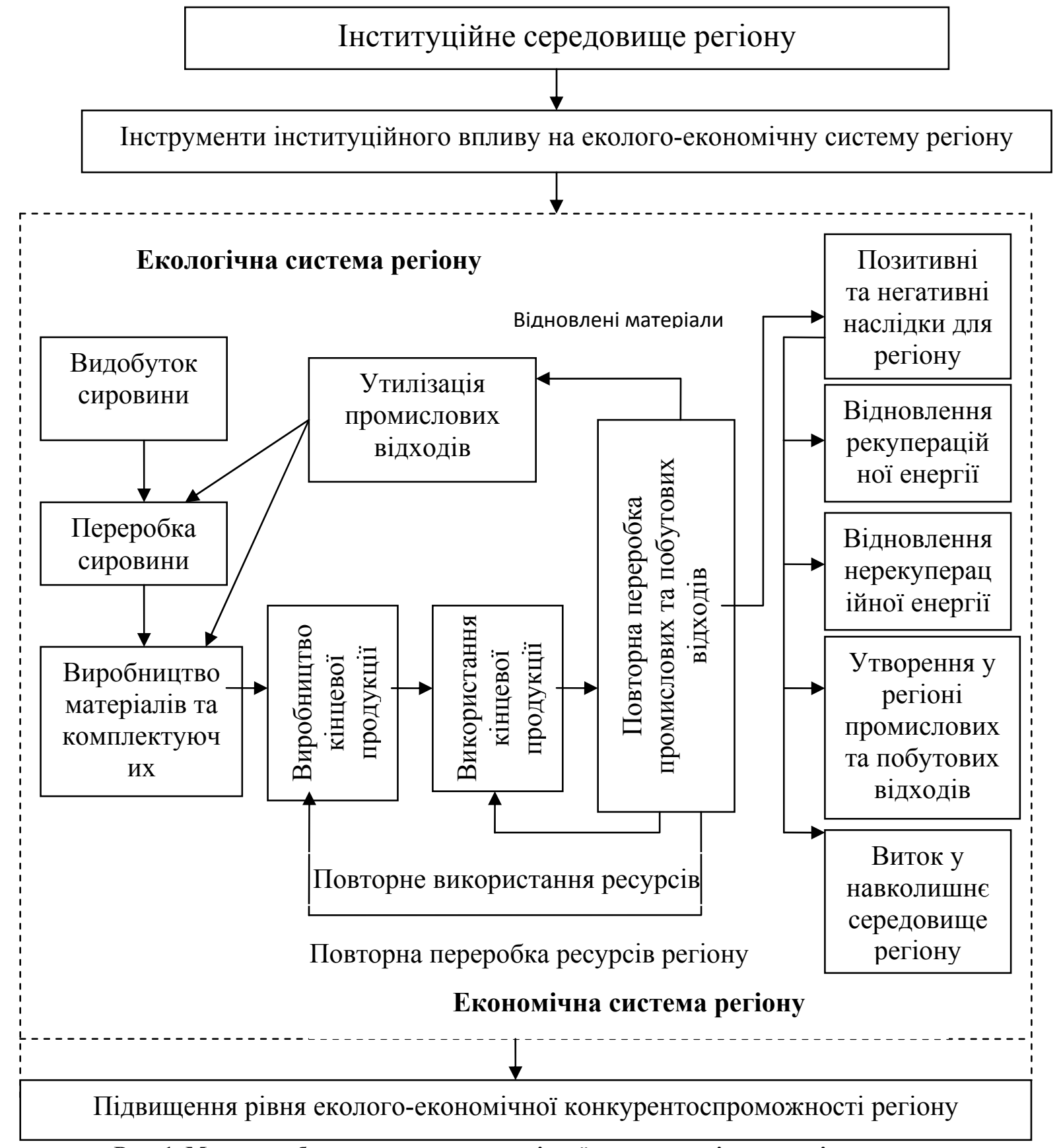

Рис. 1. Модель побудови еколого-економічної системи регіону для підвищення рівня його конкурентоспроможності Джерело: розробка автора

При цьому необхідно так упорядкувати економічні структури, щоб збільшити вихід продукції, тобто необхідно виявити причини високої природомісткості економіки і боротися саме 3 ними, а не 3 їх негативними наслідками.

У процесі екологізації економічного розвитку, вироблення інтенсивного і водночас зберігаючого підходу до природокористування нам видається важливою орієнтація на кінцеві результати, що враховують як економічну так і екологічну складову. Для традиційного екстенсивного мислення обсяги використовуваних природних ресурсів - найважливіші показники. На нашу думку, більш важливими показниками економічної діяльності на регіональному рівні $\epsilon$ обсяги економії використовуваних природних ресурсів, що пов'язує природу та продукцію, яка надійшла до споживача, для якого головне обсяги і якість кінцевої продукції, а не те, скільки природних ресурсів задіяно в ії виробництві. У цих 
умовах необхідно врегулювати регіональні виробничі потоки не від наявних у регіоні природних ресурсів та можливостей їх залучення у виробничий процес, а від потреб споживача до максимально можливого використання альтернативних джерел ресурсів [6].

Природна сировина та продукти іï переробки, що послідовно інтегруються у різні види економічної діяльності відповідних сфер та галузей, повинна поєднуватись технологічно для виробництва та реалізації кінцевої продукції. Раціоналізація будь-якої ланки у природно-продуктовому ланцюжку неминуче позитивно відіб'ється на якісному стані природно-ресурсного потенціалу території. Побудова такого ланцюжка дасть можливість на регіональному рівні послідовно оцінити та виявити резерви природних ресурсів, які нині використовуються нераціонально. Якщо розглядати питання 3 точки зору екологізації економіки, виникає необхідність в аналізі факторів виробництва 3 позицій кінцевих результатів, можливості застосування альтернативних видів ресурсів, для економії природних ресурсів при збереженні й збільшенні кінцевого виходу продукції. Природний фактор, жива праця та штучно створені засоби виробництва є ресурсами, що доповнюють один одного, а випуск продукції припускає обов'язкову участь різних комбінацій усіх цих факторів у виробничому процесі. У міру економічного розвитку можливе використання одного фактору виробництва замість іншого, тобто проявляється принцип взаємозамінності факторів виробництва. Високою еластичністю відносно обсягів використовуваних природних ресурсів характеризуються витрати праці та засобів виробництва в обробляючих, високотехнологічних та інфраструктурних галузях. Розвиток цих галузей дає змогу повніше використовувати конкретний природний ресурс або продукцію, отриману на його основі, комплексно їх обробляти, усувати втрати через недосконалість переробки [7].

Отже, знизити навантаження на природні ресурси регіону дозволяє оптимізація взаємодії факторів виробництва, оскільки в основі визначення реальних потреб у природних ресурсах лежить принцип урахування взаємозамінності виробничих ресурсів. Необхідно оцінювати природні ресурси і одержувану на їх основі продукцію як єдину природно-продуктову систему i 3 позицій кінцевих результатів функціонування цієї системи визначати необхідні обсяги та ефективність використання природних ресурсів. Саме таким чином може бути значно знижена інтенсивність використання природно-ресурсного потенціалу території при одночасному збільшенні величини споживання кінцевої продукції.

В умовах, пов'язаних і з процесами глобальної конкуренції, і з новими формами інтеграції та диференціації регіонів, особливого значення набуває прискорення темпів науково-технічного прогресу та загострення уваги на ресурсно-еколого-економічній складовій. Процес розробки напрямів інституційного розвитку еколого-економічної конкурентоспроможності регіонів 3 урахуванням ресурсо-екологоекономічних можливостей та оптимізації територіальної структури економічної системи, дає підстави сформувати перелік стратегічних пріоритетів іiі зміцнення, що стосуються модернізації системи внутрішнього ринку, забезпечення інвестиційно-інноваційного розвитку суб'єктів базових галузей економіки регіонів.

Світовий досвід переконливо свідчить, що досягнення стратегічних пріоритетів і конкурентних переваг регіону $\epsilon$ можливим лише при умовах впровадження активної економічної мотивації для господарських суб'єктів, які здійснюють ефективний пошук альтернативних напрямів щодо ресурсозаміщення у всіх сферах виробничої та невиробничої діяльності. Застосування відповідних стимулів для потреб підприємців і населення регіону забезпечує участь наукової та інноваційної сфери у вирішенні соціальних, економічних, екологічних проблем та сприяють посиленню конкурентоспроможності на регіональному рівні. На сучасному етапі важливо забезпечити весь комплекс напрямів і заходів, що реалізуються у рамках регіональної економічної політики для підвищення інноваційної активності регіонів, що забезпечить максимально повну реалізацію економічного потенціалу інституційного розвитку екологоекономічної конкурентоспроможності регіонів для формування високопродуктивної еколого-економічної системи.

Висновки. При розробці напрямів і конкретних заходів щодо забезпечення інституційного розвитку еколого-економічної конкурентоспроможності регіонів необхідний системний підхід, що передбачає необхідність вивчення інституційних особливостей регіонів України, створення сприятливого економічного та правового середовища, удосконалення інфраструктури розвитку регіональних систем, послідовності вдосконалення інституційних умов та інструментів екологічної політики, чого неможливо досягти без проведення стимулювання розвитку регіонів органами державної та регіональної влади.

Системний вплив різних державних та регіональних інституцій на ситуацію у регіонах може забезпечити позитивну динаміку, а також збільшення конкурентного потенціалу, що здатний впливати на їх сталий розвиток. Держава при активній взаємодії з іншими суб'єктами господарювання повинна ініціювати формування якісно нових інституційних основ нової моделі розвитку, де гармонійно поєднується управління економічними, екологічними і соціальними чинниками, що сприяють забезпеченню високих соціальних, економічних та екологічних стандартів життя населення та підвищенню конкурентоспроможності на регіональному рівні.

Поступальний розвиток взаємодії еколого-економічних процесів, необхідність подальшого створення нових ефективних інститутів на екологічних засадах, припускають в рамках еволюції системи розвитку багатосторонніх інститутів регіонального управління. До основних стратегічних напрями реформування організацій і форм взаємодії еколого-економічних процесів та інститутів можна віднести: 
- дієве використання такої традиційної та ефективної ринкової форми, як біржа;

- паралельне створення міжнародної екологічної організації нового типу, що активно використовує багатосторонні режими з різними функціями та селективно обирає найбільш ефективні 3 точки зору суспільних інтересів організації та інститути. Такий розвиток об'єктивно тягне за собою новий виток удосконалення загальної структури системи взаємодії еколого-економічних процесів та інститутів.

Слід зазначити, що програмні та інші документи державного рівня повинні служити базою при розробці регіональних програм переходу до сучасної еколого орієнтованої економіки і разом з відповідними законами, правовими актами та нормативами визначати економічні, екологічні та соціальні умови їх реалізації, хоча донесення до населення реальної інформації і забезпечення прогресивних зрушень в даному напрямку на сьогоднішній день є проблемним.

\section{Список використаних джерел.}

1. Cobuild C. (2011) Business Vocabulary in Practicee. Collins Cobuild,. 256 p.

2. Mascull B. (2010) Business Vocabulary in Use. Cambridge University Press, 176 p.

3. Ларіна О. Г. Оцінка конкурентоспроможності регіонів в американській та європейській моделі розвитку. Науковий вісник ЧДЕІУ. 2011. № 2 (10). С. 54-59.

4. Просович О.П., Бондаренко Ю.Г., Прийма Л.Р. Стратегія інноваційно - інвестиційного розвитку регіону в умовах економічної кризи. Вісник Національного університету «Львівська політехніка». Проблеми економіки та управління. 2009. № 640. С. 183 - 188.

5. Стегней М.І. Інвестиційно-інноваційні домінанти сталого розвитку територіальних одиниць. Економіка і суспільство. 2015. №1. С. 45-51.

6. Юрків Н. Я. Економічні та інституційні передумови економічної безпеки в реальному секторі економіки. Управління проектами та розвиток виробництва. 2012. № 1. С. 44-50.

7. Яценко О.В. Напрямки розвитку інвестиційно-інноваційної діяльності підприємств. Збірник наукових праць ЧДТУ. 2014. №21. С. 192-196.

\section{References.}

1. Cobuild, C. (2011), Business Vocabulary in Practice, Collins Cobuild, HarperCollins, NY, USA.

2. Mascull, B. (2010), Business Vocabulary in Use, Cambridge University Press, Cambridge, UK.

3. Larina, O. H. (2011), "Assessment of regional competitiveness in the American and European model of development”, Naukovyy visnyk ChDEIU - Scientific Bulletin of the ChSEIU, vol. 2 (10), pp.54-59.

4. Prosovych, O.P. Bondarenko, Yu.H. and Pryyma, L.R. (2009), "Strategy of innovation - investment development of the region in the conditions of economic crisis", Visnyk Natsional'noho universytetu "L'vivs'ka politekhnika». Problemy ekonomiky ta upravlinnya - Bulletin of the National University "Lviv Polytechnic". Problems of economy and management, vol. 640, pp.183 - 188.

5. Stehney, M.I. (2015), "Investment-innovative dominants of sustainable development of territorial units", Ekonomika i suspil'stvo - Economy and society, vol. 1, pp.45-51.

6. Yurkiv, N. Ya. (2012), "Economic and institutional prerequisites for economic security in the real economy", Upravlinnya proektamy ta rozvytok vyrobnytstva - Project management and production development, vol. 1, pp.44-50.

7. Yatsenko, O.V. (2014), "Directions of development of investment-innovative activity of the enterprises", Zbirnyk naukovykh prats' ChDTU - Collection of scientific works of ChSTU, vol. 21, pp.192-196. 